\title{
O Sindicalismo Revolucionário argentino e a Revolução Russa
}

\author{
Fernando Sarti Ferreira ${ }^{1}$
}

Resumo: Os impactos da crise revolucionária mundial de 1917-1921 no movimento operário e nos agrupamentos de esquerda argentinos, especialmente do seu evento mais espetacular, a Revolução Russa, já foram amplamente discutidos e abordados em diversos trabalhos. Por sua vez, essa literatura teve seus impactos estudados com especial ênfase fosse no movimento anarquista ou no incipiente comunismo argentino. Porém, em relação aos Sindicalistas Revolucionários, que naquele momento dirigiam as principais organizações operárias do país após terem realizado o até então mais bemsucedido esforço de organização do proletariado naquele país, muito pouco foi escrito acerca dos impactos dos "ventos de Petrogrado" sobre tais militantes, especialmente aqueles organizados na Federación Obrera Regional Argentina del IX $X^{o}$. Neste artigo, o objetivo é abordarmos os impactos da Revolução Russa sobre os Sindicalistas Revolucionários e como se delinearam frente ao evento duas posições irreconciliáveis sobre os rumos do movimento operário argentino em um momento decisivo para a luta dos trabalhadores no país.

Palavras-chave: Revolução Russa; Movimento Operário; Argentina

\section{Argentine Revolutionary Syndicalism and the Russian Revolution}

Abstract: The impacts of the world revolutionary crisis of 1917-1921, but especially on its most spectacular event, the Russian Revolution, on the workers' movement and on the left-wing groups of Argentina, have already been widely discussed and approached by various scholars. In turn, in this literature, these impacts were approached with special emphasis either on the anarchist movement or the incipient Argentine communism. In relation to the Revolutionary Syndicalists, who were leading the main workers' organizations of the country, after having made the most successful effort to

\footnotetext{
${ }^{1}$ Doutorando em História Econômica pela Universidade de São Paulo (USP), Brasil. Pesquisador Associado do Laboratório de Economia Política e História Econômica da Universidade de São Paulo. Email: fernandosartiferreira@yahoo.com.br
}

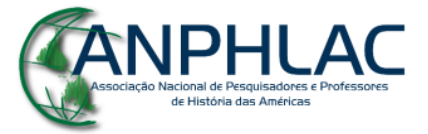


organize the proletariat in that country, very little was written about the impact of the "Petrograd winds" on these militants, especially on the Federación Obrera Regional Argentina del IX $X^{o}$. In this article, we intend to address the impacts of the Russian Revolution on the Revolutionary Syndicalists and how these two irreconcilable positions on the direction of the Argentine labor movement were drawn around these debates at a decisive moment for the workers' struggle in that country.

Keywords: Russian Revolution; Labour Movement; Argentina

Artigo recebido em: 23/03/2018

Artigo aprovado em: 21/09/2018

\section{Introdução}

A historiografia argentina dedicou-se a estudar os impactos do processo revolucionário russo no movimento operário de seu país sob duas perspectivas. Por um lado, como o evento fundamental para compreender o surgimento do Partido Comunista Argentino (ISCARO, 1973; ARÉVALO, 1983; CORBIÉRE, 1984; ORIOLO, 1994; CAMARERO, 2007), uma das principais organizações da esquerda do país e cuja influência sobre os trabalhadores argentinos foi determinante nas décadas de 1930 e 1940. Por outro lado, como um evento responsável por reavivar e, quiçá, o último ato relevante de um movimento anarco-sindicalista, que nem de longe lembrava aquele das décadas anteriores (DOESWIJK, 1998; PITTALUGA, 2002). Curiosamente, a descrição e análise dos impactos da Revolução Russa na organização e na direção da corrente política que hegemonizava o movimento operário argentino naquele período a Federación Obrera Regional Argentina del IX Congreso (FORA IX'), controlada pelos Sindicalistas Revolucionários ${ }^{2}$-, foram temas muito pouco explorados.

\footnotetext{
${ }^{2}$ A FORA IX ${ }^{\circ}$ foi criada como resultado da fusão em 1914 de duas federações sindicais, a saber, a FORA - de orientação anarco-sindicalistas - e a Confederación Obrera de la Región Argentina (C.O.R.A.) - de orientação Sindicalista Revolucionária. Uma dissidência que reivindicava o anarquismo como orientação ideológica rompeu durante o $9^{\circ}$ congresso no ano de 1915 e refundou a FORA sob os princípios do
}

\section{CANPHLAC}


Neste artigo, por meio da análise dos dois principais jornais operários da época, o La Vanguardia (LV), ligado ao Partido Socialista, e o La Organización Obrera (LOO), órgão de imprensa da principal organização sindical do país no período ${ }^{3}$, buscamos descrever e analisar como os Sindicalistas Revolucionários tampouco ficaram alheios aos "ventos de Petrogrado". Atentando às interações entre sindicatos, patronais, Estado e partidos políticos ao longo do período de 1917-1921, indicamos como se delinearam naquele momento, impulsionados pelo efeito catártico que a revolução teve nas bases do movimento operário em um contexto de agudos conflitos sociais, no seio da direção Sindicalista Revolucionária, duas posições irreconciliáveis sobre os rumos do movimento operário argentino, cujos debates sobre a Revolução Russa acabaram expressando.

\section{A Revolução mundial.}

A Primeira Guerra Mundial arrastou consigo para o turbilhão revolucionário um sem número de regiões e Estados nacionais, direta e indiretamente envolvidos no conflito. Segundo Eric Hobsbawm, "A velha sociedade, a velha economia, os velhos

“comunismo anárquico". Desde então ficou convencionado em identificar a FORA de orientação majoritariamente Sindicalista Revolucionária pela adição do IX e a FORA de orientação anarquista pela adição do $\mathrm{V}^{\mathrm{o}}$, em referência ao $5^{\circ}$ congresso de 1904 , quando se adotaram os princípios do "comunismo anárquico". A fundação dessa organização marca o início da hegemonia dos Sindicalistas Revolucionários na condução do movimento operário argentino. Entre 1890 e 1914, a lealdade política dos trabalhadores na Argentina era disputada basicamente por três grandes correntes, a saber, o socialismo, o anarco-sindicalismo e o Sindicalismo Revolucionário. Os socialistas argentinos se organizavam em torno do Partido Socialista. A organização, cuja figura de proa era o médico e intelectual Juan B. Justo, era inspirada pelo chamado reformismo socialdemocrata da Segunda Internacional e enfatizava a necessidade de que a luta dos trabalhadores extrapolasse os marcos sindicais e viabilizasse a organização política e parlamentar destes. Como principais antagonistas dos socialistas, os anarcosindicalistas defendiam a ação direta e a construção da greve geral revolucionária. Depositando suas energias na construção de sindicatos e da Federación Obrera Regional Argentina, desprezavam a ação parlamentar e relutavam frente a quaisquer formas de interação com o Estado que não fossem o conflito aberto. Por fim, como uma terceira posição, surgiu na Argentina a corrente Sindicalista Revolucionária. Inspirados pelas deliberações do Congresso da CGT francesa, em Amiens, no ano de 1906, quando a organização reafirmou como objetivo final a destruição do capitalismo e sua total independência do Estado e dos partidos políticos, na Argentina, os Sindicalistas Revolucionários constituíram uma posição intermediária entre anarquistas e socialistas. Por mais que reconhecessem a necessidade de destruir a ordem capitalista, os Sindicalistas Revolucionários argentinos acreditavam ser fundamental a luta sindical, sem importar as formas, meios ou fins que esta assuma. Por fim, optou-se pelas letras maiúsculas para diferenciar a corrente política e tudo o que se refere a ela do uso corrente das palavras "sindicalismo", "sindicalista" e "revolucionário".

${ }^{3}$ Para a elaboração deste trabalho foram consultados os exemplares microfilmados do La Vanguardia na Biblioteca Nacional Mariano Moreno e a coleção de originais da Biblioteca Obrera Juan B. Justo, ambos em Buenos Aires. Já os exemplares originais do La Organización Obrera foram consultados na Biblioteca 17 de Octubre no Sindicato de Obreros y Empleados de la Madera, também na Capital Federal.

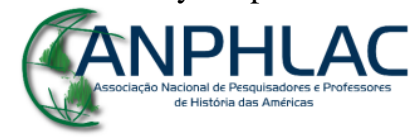

Revista Eletrônica da ANPHLAC, ISSN 1679-1061, №. 25, p. 28-55, Jul./Dez., 2018.

http://revista.anphlac.org.br 
sistemas políticos tinham (...) 'perdido o mandato do céu"'. A crise econômica, política e social desencadeada pela guerra atingiu, em maior ou menor grau, todos aqueles que tinham qualquer relação com o sistema de trocas impessoais do mercado mundial (HOBSBAWM, 1995, p. 62). As mobilizações e conflitos sociais dos últimos dois anos de guerra, e que perduram até o início da década de 1920, frequentemente evoluíram de protestos contra a penúria material para motins contra a guerra, rebeliões e mesmo para insurreições que colocaram em xeque a existência da "velha sociedade", como as revoluções na Rússia (1917-1921), na Alemanha (1918-1919) e na Hungria (1919). As greves massivas de trabalhadores, que muitas vezes adquiriram conotações insurrecionais, foram a principal expressão do espírito de rebeldia que tomou conta de todo o mundo entre os anos de 1917 e 1921.

Em um estudo clássico sobre tal período dedicado à Europa, Charles Maier dividiu a vaga revolucionária mundial ao fim da Primeira Guerra em três momentos: 1917-1919, quando ocorreu uma "onda apocalíptica da militância de esquerda", pontuada por greves gerais e que levaram tanto os agentes da transformação como os quadros da ordem a acreditarem que o mundo viria abaixo; 1919-1921, quando continuou existindo uma vívida militância, contudo focada em objetivos mais específicos e imediatos, fazendo com que os trabalhadores e partidos de esquerda adequassem suas táticas, consciente ou inconscientemente, frente à resiliência do capitalismo; e, por fim, de 1921 em diante, quando o movimento grevista refluiu e a esquerda e a classe operária se dividiram em diversas facções (MAIER, 1998, p. 136). Os números de filiados às centrais sindicais ligadas à Federação Sindical Internacional (FSI), com sede em Amsterdam ${ }^{4}$, além dos dados sobre greves no período, comprovam em linhas gerais a periodização estabelecida por Maier.

\footnotetext{
${ }^{4}$ Federação Sindical Internacional, também conhecida como Internacional Sindical de Amsterdam, foi uma organização internacional fundada em 1919 e que reuniu em suas filas sindicatos ligados aos partidos socialistas e socialdemocratas que não aderiram, ou tinham severas críticas ao processo revolucionário russo.
}

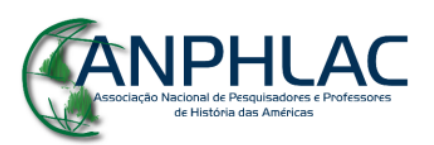




\section{Gráfico I: Índice do número de filiados}

às centrais sindicais ligadas à FSI $(1913=100)$

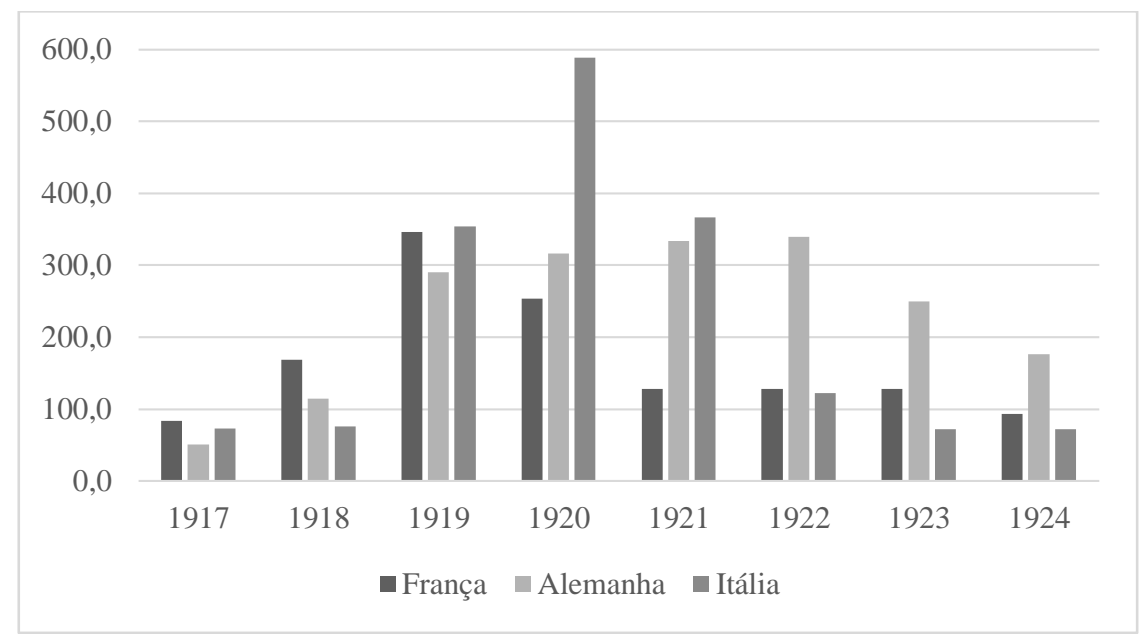

Fonte: FSI, 1938.

\section{Gráfico II: Greves e grevistas em países selecionados, 1917-1923}

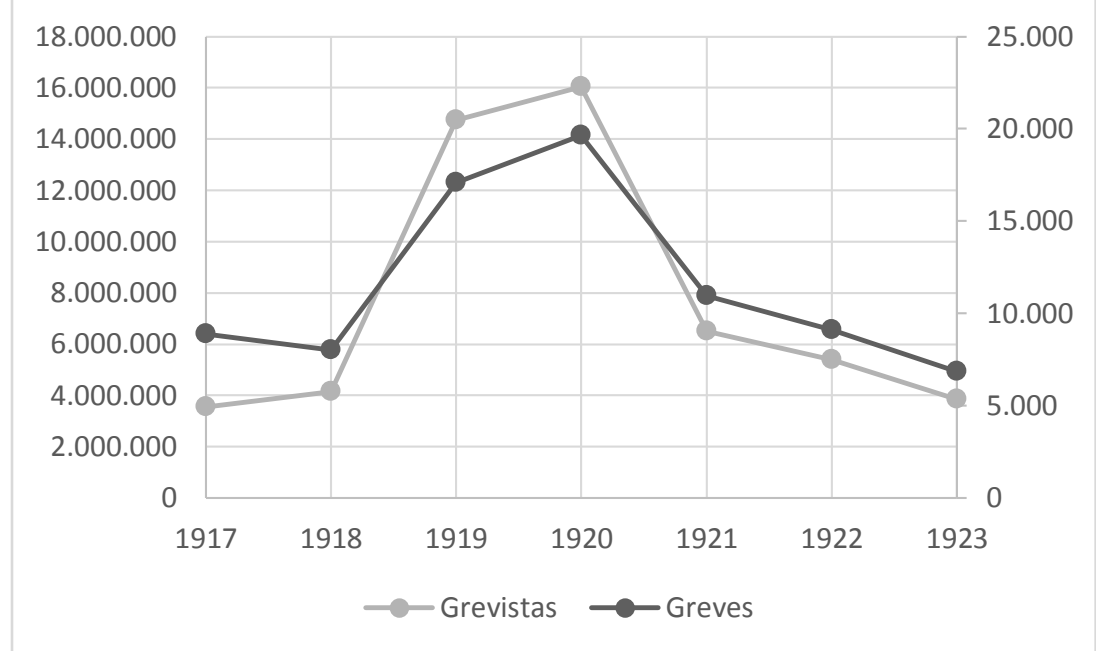

Fonte: Elaborado a partir de FLORA, KRAUS e PFNENING, 1987, p. 679-753; PETERSON, 1938, p. 40-50; DNT, 1919-1940.

Entre 1917 e 1919, ocorre uma verdadeira explosão de mobilização e organização dos trabalhadores, seguida de um período quando, em que pese a continuidade da militância operária, esta passa longe de manter o mesmo ritmo de

\section{GANPHLAC}

Revista Eletrônica da ANPHLAC, ISSN 1679-1061, №. 25, p. 28-55, Jul./Dez., 2018.

http://revista.anphlac.org.br 
crescimento. Pelo contrário, após atingirem um teto no ano de 1920, com quase 20.000 greves e 16 milhões de grevistas ao redor do mundo, a onda de mobilizações começou a refluir até quase atingir níveis inferiores aos anteriores ao conflito mundial, seja de greves, grevistas ou membros de sindicatos. Apesar de uma iniciativa promissora, a resiliência capitalista prevaleceu, levando o movimento insurrecional a uma série de derrotas e acomodações, finalmente trazendo importantes consequências para o desenvolvimento de seu movimento mais radical e espetacular, a Revolução Russa de $1917-1921$.

\section{A Argentina e a Revolução Mundial: a "realidade rebelde"}

A Argentina, país cujo vínculo com o mercado internacional havia sido o responsável por seu estrepitoso crescimento econômico e desenvolvimento urbanoindustrial na virada do século XIX para o século XX, não esteve alheia à tais eventos. $\mathrm{O}$ país foi duramente abalado tanto pelos efeitos econômicos provocados pelo início da guerra quanto pela onda rebelde que marcou os últimos e subsequentes anos do conflito.

Do ponto de vista econômico, as tensões na região dos Balcãs que antecederam o conflito já haviam derrubado o fluxo de capitais para o país sul-americano - uma das principais alavancas de seu crescimento econômico -, situação que apenas se agravou com o início do conflito, assim como as consequentes turbulências e redução do comércio transatlântico (BREWESTER SMITH e COLLINGS, 1920, p. 58-59; DI TELLA e ZYMELMAN, 1973, p.129-156; PALACIO, 2000, p. 108-110). Entre os anos de 1916 e 1917, o desemprego atingiu quase $20 \%$ da força de trabalho de Buenos Aires (DNT, 1921, p. 651). De 1914 à 1918, os salários recuaram em 35\%, enquanto o índice de preços ao consumidor subiu 75\% (BUNGE, FERRARI e VALLE, 1920, p. 253-260; CORTES CONDE, 1976; FERRERES, 2010, p. 581; IÑIGO CARRERA, 2007, p. 142). Essa combinação, cuja coroação se deu com a retração do PIB em 8\% entre 1916 e 1917, produziu uma crise que, segundo Guido Di Tella e Manuel Zymelman (1973, p. 156), teve “(...) intensidade comparável à crise de 1929”. Se sua intensidade pode ser comparada à de 1929, a verdade é que sua duração foi muito mais curta. A recuperação econômica, cujos sinais já começaram a se insinuar no ano de 1917, por sua vez,

\section{GANPHLAC}


funcionou como uma faísca que produziu a maior e mais importante onda de greves e conflitos trabalhistas anteriores à Segunda Guerra Mundial.

Ao analisarmos os dados coletados pelo Departamento Nacional del Trabajo ${ }^{5}$ relativos aos conflitos trabalhistas na cidade de Buenos Aires, entre os anos de 1907 e 1939 (número de greves, motivações, número de grevistas, jornadas perdidas, resultados, etc.), fica evidente, assim como observado em outros países, a importância dos conflitos ao fim da década de 1910 e começo de 1920 em termos de números de greves, de grevistas e quantidade de jornadas de trabalho perdidas. Depois de um pico do número de jornadas perdidas e de greves em 1910, mas com uma participação de trabalhadores já declinante, se comparado ao ano de 1907, as três variáveis retraíram-se e apenas voltaram a crescer a partir do ano de 1917, atingindo proporções inéditas.

Entre 1916 e 1917, o crescimento da participação de trabalhadores é notável - de 24.321 para 136.062 grevistas - e talvez ainda mais conspícua por ocorrer no momento em que a taxa de desemprego atingia 19,2\% da população economicamente ativa. As greves de 1917 foram marcantes também pela intensidade: ao redor de 15.219 jornadas perdidas e 985 grevistas por greve, a maior participação de trabalhadores por greve do período que vai de 1907 a 1922 e a segunda maior perda de jornadas, ficando atrás apenas do ano de 1920. O pico, em número de greves e grevistas, ocorreu em 1919 ano da greve geral conhecida como a Semana Trágica - com uma notável retração a partir do ano de 1922.

Ao aumento de greves, grevistas e jornadas perdidas, assim como visto acima em relação à Europa e aos EUA, fora um movimento que também na Argentina correspondia ao crescimento da organização sindical. Tal crescimento, por sua vez, ocorreu independentemente de qual fosse a orientação ideológica dessas organizações. Ao nos debruçarmos sobre os dados daquele período da então principal federação operária argentina, a Federación Obrera Regional Argentina del $X^{o}$ Congreso (FORA $\mathrm{IX}^{\mathrm{o}}$ ), de orientação Sindicalista Revolucionária e com importante participação dos socialistas, o número de cotistas mais que triplicou em relação ao ano de 1916. No

\footnotetext{
${ }^{5}$ Em decorrência dos crescentes conflitos trabalhistas, o governo federal argentino criou em 1907 o Departamento Nacional del Trabajo. A missão do órgão era monitorar e propor soluções para a então chamada "questão social". Em 1928, o departamento passou a ter o poder de fiscalizar e multar as empresas que descumpriam as leis trabalhistas do país. Foi também o principal veículo utilizado por Perón para se aproximar das organizações sindicais após o golpe militar de junho de 1943.
}

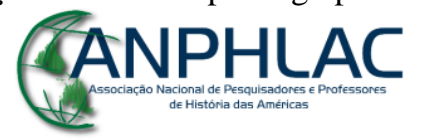


mesmo sentido, a média mensal de filiados quase quadriplicou e o número de sindicatos filiados cresceu quase três vezes (BILSKY, 1984, p. 24-30; LOO, 05/05/1922). Após a onda de greves, e assim como nas outras regiões que foram varridas por ela, não apenas o número relativo a mobilizações diminuiu abruptamente, mantendo-se baixo por um longo período, como também os sindicatos se fragmentaram e perderam um contingente importante de filiados.

\section{A Argentina e a Revolução Mundial: as três fases de Maier}

De maneira geral, podemos identificar claramente uma similaridade entre os impactos da onda revolucionária no movimento operário argentino com a periodização proposta por Charles Maier. Propomos aqui discriminar as três fases correlativas à periodização do autor estadunidense para o caso argentino. A primeira fase dessas mobilizações, concentrada sobretudo na cidade de Buenos Aires - centro político e econômico do país -, mas que ganhou no período uma projeção nacional, ocorreu entre 1917 e 1919 e teve como pano de fundo a forte recuperação econômica, embalada pela retomada das exportações. No país sul-americano, como observado na Europa e Estados Unidos, houve uma verdadeira explosão no número de greves, motivadas principalmente por reivindicações de caráter econômico (53\% das greves na Argentina foram por salários) e sendo em grande medida favoráveis aos trabalhadores (51\% dos grevistas durante o biênio tiveram algum ganho nas mobilizações).

O início da onda de greves em 1917 se deu entre os trabalhadores dos transportes, como ferroviários, marítimos e portuários, setores centrais do complexo agroexportador e da economia de guerra, cuja ação teve a inédita anuência do governo argentino sob a presidência de Hipólito Yrigoyen ${ }^{6}$. Nos anos seguintes, a agitação se disseminou por todas as categorias e ramos de produção (DNT, 1925, p. 1564-1566), tendo como ápice os eventos da Semana Trágica de janeiro de 1919.

\footnotetext{
${ }^{6}$ As interpretações sobre as razões dessa aproximação partem de uma visão apologética de Yrigoyen, ao defender seus sinceros anseios pela construção de uma sociedade harmônica (LUNA, 1985 (1954); DEL MAZO, 1986; IÑIGO CARRERA,1980; PASSALACQUA, 1984; FALCÓN, 2000), passando pelas interpretações que entenderam seu governo como a expressão de um certo bonapartismo (PUIGGRÓS, 1974; PEÑA, 1971), até a mais consagrada interpretação, que identifica tal aproximação como uma tática eleitoral específica para a industriosa Capital Federal (ROCK, 2010 (1977).
}

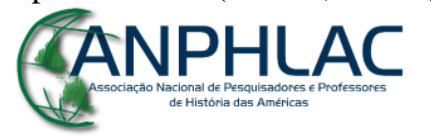


A segunda fase, ou seja, o momento em que, apesar da manutenção de uma intensa mobilização, o movimento operário começou a dar sinais de esgotamento e de transformação em suas expectativas, iniciou-se nos fins de 1919, mais precisamente com a organização da Frente Única Operária bem como as massivas demonstrações contrárias ao projeto de legislação trabalhistas enviado à Câmara de Deputados pela Comissão de Legislação Social, em junho daquele ano (DSCD, 1919, p. 165-172²). Nessa segunda fase, quando o crescimento econômico, assim como as agitações, prosseguiram, mas em ritmo mais lento, operou-se uma transformação de expectativas que se traduziu em uma reversão de resultados. Entre 1920 e 1921, as reivindicações classificadas como organizativas, ou seja, que lutavam pelo reconhecimento nos locais de trabalho das organizações sindicais, ultrapassaram as econômicas, $46 \%$ contra $40 \%$, respectivamente, levando $78 \%$ dos trabalhadores que entraram em greve à derrota.

Em relação à organização dos trabalhadores, além do já mencionado, devemos destacar que entre a primeira e a segunda fase ocorreram outros dois importantes processos, a saber, o crescimento dos sindicatos fora da capital e a organização dos trabalhadores dos ramos produtivos. Coletando os números da participação de sindicatos e delegados nos congressos da FORA IX ${ }^{\circ}$ de 1918 e $1921^{8}$, podemos expressar graficamente esses dois processos:

\footnotetext{
${ }_{8}^{7}$ Diario de Sesiones de la Camara de Diputados, referência completa ao final do texto.

8 Todas as informações relativas aos sindicatos e delegados participantes dos dois Congressos da F.O.R.A. IX ${ }^{\mathrm{a}}$ foram retiradas de: SANTILLAN, 2005 (1933); NIKLISON, 1919; LOO 04/01/1919 e 12/02/1921. Sobre o crescimento da organização operária, devemos destacar não apenas a dispersão dos trabalhadores dos transportes pelas redes ferroviárias e fluviais do país, como também pelas chamadas giras de propaganda empreendidas pela direção da federação naqueles anos (ver LOO, 18-25/02/1921, assim como LOO, 20/09/1919 e LOO, 23/03/1920.
}

\section{GANPHLAC}


Gráfico III: Número de sindicatos classificados por ramo de produção representados nos congressos da F.O.R.A. IX ${ }^{\circ}$ de 1918 e 1921

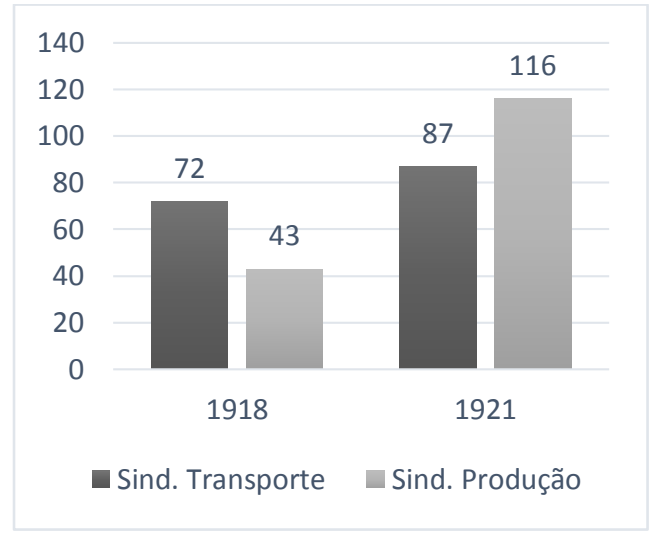

Gráfico IV: Número de sindicatos classificados por região do país representados nos congressos da F.O.R.A. IX ${ }^{\circ}$ de 1918 e 1921

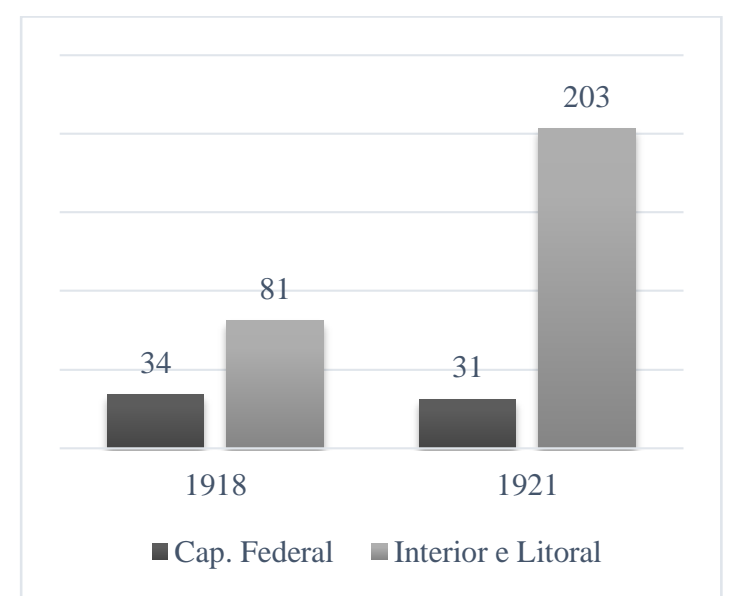

Por fim, tanto os dados estatísticos do Departamento Nacional del Trabajo quanto a literatura sobre o período (SANTILLAN, 2005 (1933), p. 270; MAROTTA, p. 183-187; GODIO, 1988; GUTIERREZ e ROMERO, 1995; FALCÓN e MONSERRAT, 2000) dão conta de uma diminuição da atividade grevista e de um recuo da militância sindical, assim como da fragmentação do movimento operário, principalmente a partir da fracassada tentativa de greve geral em junho de 1921. Além da redução abrupta dos conflitos grevistas, o número de filiados às organizações operárias despencou: de uma média de 53.570 cotistas mensais que a FORA IX ${ }^{\circ}$ teve em 1921, enquanto que em

\section{GANPHLAC}


1922, quando a organização se transformou na Unión Sindical Argentina, a média mensal de cotista despencou para 41.794.

\section{A Argentina e a Contrarrevolução internacional: breves comentários sobre as organizações patronais e o Estado}

Antes de avançarmos sobre as implicações da Revolução Russa sobre a principal organização operária argentina do período, urge tecer alguns comentários específicos sobre as reações do Estado e das organizações patronais frente a tal "militância apocalíptica" da classe operária, uma vez que "Não pode haver Revolução sem contrarrevolução; ambas, como fenômeno e processo, são inseparáveis" (MAYER, 2000, p. 45) ${ }^{9}$.

Algo fundamental para a Reação na Argentina foi o duplo movimento empreendido pelas organizações patronais ao longo das duas primeiras fases da explosão de mobilizações e que resultaram em sua vitória, como demonstram os dados relativos aos conflitos operários a partir de 1921. Por um lado, os mais diversos setores empresariais se moveram no sentido de dirimir seus conflitos internos e unificar suas ações frente ao movimento operário. É nesse sentido que podemos entender a criação em 1917 da Confederación Argentina del Comercio, de la Industria y de la Produción (CACIP) - organização que passou a reunir em suas filas as principais organizações industriais, comerciais e agropecuárias (MARCHESE, 2000) -, a reforma estatutária da Unión Industrial Argentina (UIA) em benefício dos grandes grupos empresariais daquele ramo (CÚNEO, 1984; SCHVARZER, 1991) e o nascimento em julho de 1918, assim como o incremento de atividades da Associación del Trabajo (AT), entre 1919 e 1920 (RAPALO, 2012). Por outro lado, a Semana Trágica de janeiro de 1919 terminou por parir a Liga Patriótica Argentina (LPA) (DEUTSCH, 2003), organização irmã da AT e principal grupo paramilitar utilizado pelas organizações patronais em conflito com os sindicatos, demonstrando claramente uma posição mais ofensiva e organizada por parte dos grupos empresariais.

\footnotetext{
${ }^{9}$ Sobre a importância das interações estratégicas entre patrões, Estado e trabalhadores como relações fundamentais para a compreensão dos movimentos grevistas, ver: FRANZOSI, 1995 e TILLY, 1989.

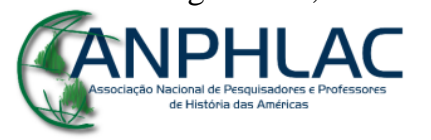


Em relação ao governo de Hipólito Yrigoyen, a brutal repressão ao movimento operário em janeiro de 1919, além de não diminuir a desconfiança que despertava nos setores conservadores e empresarias por sua aproximação aos sindicatos, colocou este em uma situação desconfortável frente aos trabalhadores organizados. A incapacidade de sua aliança com alguns sindicatos para domar as mobilizações e, consequentemente, a contundente decisão das patronais de resolver a "questão social", dando claros sinais de que estava disposta a criar uma crise de Estado para tanto, finalmente dobraram Yrigoyen em maio e junho de 1921. Os operativos policiais que se anteciparam ao chamado de greve geral, em junho de 1921, concluíram o processo de afastamento do presidente da FORA IX ${ }^{\mathrm{a}}$, iniciado após a Semana Trágica, mas principalmente quando o poder executivo excluiu a organização da delegação argentina para o Congresso da OIT, em Washington, em novembro de 1919. A escolha de um delegado ferroviário coroou a viragem da política obrerista de Yrigoyen de abandonar o unionista sindicato dos marítimos como seu principal interlocutor e optar pelos "mais responsáveis" e isolacionistas ferroviários (GOLDEBERG, 1979, p. 217; HOROWITZ, 1985, p. 426; HOROWITZ, 2001, p. 244-245).

\section{A Revolução Russa e o dilema da FORA IX ${ }^{0}$ : radicalização ou autodefesa?}

No dia 18 de setembro de 1920, a edição do La Organización Obrera, semanário da FORA IX', estampou em letras garrafais em sua capa a seguinte notícia: "Una Federación Sindical Internacional Roja? Circular de Zinovieff propiciando la escisión en el movimiento obrero mundial". Na breve introdução ao texto de Zinoviev, Luiz Lauzet - trabalhador gráfico, editor do semanário e membro do Conselho Federal (C.F.) - anunciava que havia se concretizado o que até pouco tempo não havia passado de uma suspeita baseada em diversos informes provenientes da França e da Inglaterra: a Internacional Comunista (IC) havia resolvido propor a formação de outra federação internacional de sindicatos, confirmando os "propósitos divisionistas a respeito do movimento operário nacional e internacional dos dirigentes da denominada 'terceira Internacional comunista"'(LOO, 18/09/1920).

O texto assinado pelo revolucionário russo, publicado na imprensa operária europeia e reproduzido na Argentina, resumia as formulações e decisões sobre o

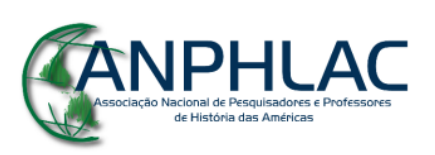

Revista Eletrônica da ANPHLAC, ISSN 1679-1061, №. 25, p. 28-55, Jul./Dez., 2018.

http://revista.anphlac.org.br 
movimento sindical tomadas no Segundo Congresso da Internacional Comunista, realizado entre os meses de julho e agosto daquele ano na cidade de Petrogrado ${ }^{10}$. Se o Primeiro Congresso - apesar de marcar o nascimento desse novo organismo revolucionário - teve resultados parcos, o Segundo, com a presença de um número quatro vezes maior de delegados, pôde avançar em questões mais práticas, tais como a elaboração das 21 condições de adesão à IC e a consolidação de uma nova linha revolucionária para o movimento operário mundial baseada na experiência bolchevique (CARONE, 2003).

Zinoviev denunciava em seu texto as organizações sindicais europeias que “opuseram pouca resistência à guerra imperialista. Ao contrário, se colocaram à disposição dos governos”. Segundo a circular, a capitulação das organizações sindicais era consequência direta da forte burocratização, da neutralidade política e do direcionamento dos sindicatos para o estreito horizonte das lutas econômicas. Essa política protagonizada pelo que Zinoviev chamou de "antigas organizações sindicais" enveredou o movimento operário para defesa da ordem burguesa ao ponto de na Alemanha e na Hungria transformarem em verdugos da classe operária membros de suas próprias filas militantes

Apesar da política de colaboração entre as "antigas organizações sindicais" e os governos nacionais, os trabalhadores construíram, ao fim do conflito, massivas mobilizações contrárias à guerra e à carestia. Para Zinoviev, era hora do

(...) novo movimento sindical [...] libertar-se resolutamente das relíquias da antiga rotina. Deverá realizar, coordenadamente com o Partido Comunista, a luta direta pela ditadura do proletariado e a autoridade dos conselhos. E deve renunciar às melhorias ajustadas ao programa reformista

Os trabalhadores, ainda segundo o revolucionário russo, deveriam lutar pela organização sindical por ramos de indústria como instrumento de combate à aristocracia operária organizada por ofícios e profissões e pela socialização das principais indústrias, privilegiando como arma a greve geral. Para tanto, era chegada a hora reconstruir uma organização internacional dos trabalhadores: “À F.S.I. amarela (...) é preciso opor a

\footnotetext{
${ }^{10}$ Para as questões discutidas e decisões adotadas naquele congresso, ver "El movimiento sindical, los comités de fábricas y de empresas", in Los Cuatro Primeros Congresos de la Internacional Comunista, V1. I, Buenos Aires: Ediciones Pasado y Presente, 1973, p. 141-150.
}

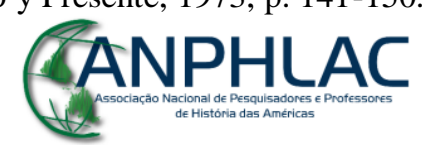


verdadeira Federação Sindical Internacional proletária vermelha”. Afirmava Zinoviev que "Como todos os grandes partidos operários se separaram da II Internacional, as diferentes federações estarão obrigadas a romper com a Federação Sindical Internacional de Amsterdam". A circular ainda garantia a intenção da IC de reunir "não somente as organizações políticas do proletariado, senão também as organizações operárias". Os sindicatos deveriam participar dos congressos da Internacional Comunista organizados como seções da Terceira Internacional. Concluía pedindo "que as federações incluíssem na ordem do dia de suas assembleias nosso chamado".

A convocatória de Zinoviev teve como efeito expor publicamente duas posições que se construíram no seio da direção sindicalista revolucionária: o que fazer diante dos impasses que se colocaram ao movimento operário a partir do fim de 1919 ?

\section{A direita}

Os Sindicalistas Revolucionários, principalmente depois do $\mathrm{IX}^{\circ}$ Congresso da FORA, realizado em 1915, passaram a implantar paulatinamente uma série de transformações na estrutura organizativa da federação que apontavam para três caminhos: a neutralidade partidária e doutrinária em nome do princípio de unidade da classe operária; a adoção de táticas de mobilização que não levassem ao conflito aberto com as forças repressivas, e, por fim, a consolidação da organização por meio de códigos mais rígidos e formais, referentes à representação e às funções desempenhadas pelos órgãos da federação, além da substituição da organização por ofícios por ramo da indústria.

Em artigo publicado no La Organización Obrera de abril de 1920 (LOO, 23/04/1920), Sebastián Marotta sistematizava quais deveriam ser os passos a serem seguidos pela organização a partir daquele momento. Para o dirigente, o enorme crescimento e a dimensão nacional que a Federação havia atingido desde seu IX $^{\mathrm{o}}$ Congresso em 1915 era o resultado da política acertada de seu Conselho Federal, mas sobretudo fora atribuída à libertação da organização das sectárias lutas ideológicas. Frente a tal cenário de crescimento (520 sindicatos, nove federações locais e seis federações por ramo industrial) e da dimensão nacional que a organização atingiu

\section{GANPHLAC}


(presente nas 14 províncias e em nove dos 16 Territórios Nacionais), Marotta afirmava que "A carta orgânica que rege atualmente a FORA não responde já às suas necessidades. Forçosamente (...) sua revisão se impõe no próximo Congresso”. Tal revisão buscaria primordialmente que "As disposições passivas que contêm atualmente deverão transformar-se em ativas". Reconhecia Marotta que as decisões adotadas pelo $\mathrm{X}^{\mathrm{o}}$ Congresso foram completamente ofuscadas pelos eventos desencadeados seis dias após seu término nas primeiras horas de janeiro de 1919.

As "disposições passivas" que deveriam ser ativadas diziam respeito principalmente a três principais transformações na federação. Em primeiro lugar, deverse-ia adotar o modelo de organização por ramos de atividade, uma vez que este ampliava o poder de luta dos trabalhadores, mas também educava a classe, para quando esta fosse reorganizar a produção, e a capacitava para assumir a gestão e direção de todo um sistema de organização industrial. Em segundo lugar, Marotta defendia o fortalecimento das federações locais, tanto para ampliar a capacidade de luta dos sindicatos mais frágeis nas regiões mais longínquas como para coordenar de maneira mais efetiva as intervenções dos trabalhadores em questões de alcance provincial e nacional. Em terceiro lugar, a maior consistência das organizações regionais livraria os membros do Conselho Federal da FORA IX ${ }^{\mathbf{0}}$ de terem de auditar, respaldar e intervir, nas ações sindicais de todo o país. Por fim, e como consequência dessas três modificações, o Conselho Federal seria esvaziado de seu conteúdo político, transformando-se em uma mera comissão administrativa, a qual deveria se encarregar de cumprir as linhas gerais de ação deliberadas em Congressos gerais realizados a cada dois anos. Frente ao impasse em que se encontrava o movimento argentino, Marotta sugeria reforçar e aprofundar a política que até então havia dirigido a federação.

Por outro lado, a Circular Zinoviev constituiu-se como um apoio para os setores do Conselho Federal que entendiam tal modelo como justamente o responsável pela estagnação do movimento operário. Apesar de nas edições seguintes Luiz Lauzet (LOO, $18 / 09 / 1920 ; 25 / 09 / 1920 ; 02 / 10 / 1920)$ ter denunciado que muitos daqueles que opinavam em concordância com Zinoviev o faziam por terem mais em conta "sua condição de militantes de um partido que sua qualidade de produtores" (LOO, 02/10/1920), apelando para o princípio da neutralidade ideológica e da conspiração das

\section{GANPHLAC}


“organizações políticas" contra o sindicato, a verdade era que a adesão à convocação da IC havia “contaminado" as fileiras do próprio Sindicalismo Revolucionário.

\section{A esquerda}

O fortalecimento e a consolidação do modelo sindical construído nos últimos anos ou a radicalização das mobilizações, divergência traduzida no seio do Conselho Federal como o debate pela adesão ou não à IC, estava prestes a explodir naquele segundo semestre de 1920. Em uma reunião do Conselho Federal, no dia 30 de agosto, a proposta de uma greve geral em solidariedade à Revolução Russa, sugerida pelo ferroviário Vicente Todaro e pelo gráfico Bartolomé Senra Pacheco, fora derrotada por apenas dois votos (LOO,18/09/1920). Essas divergências se expressariam novamente à ocasião da divulgação da circular Zinoviev. A abertura das páginas do La Organización Obrera para a discussão da convocatória feita pela IC havia sido consequência de uma longa reunião do Conselho Federal da FORA IX', realizada no dia 23 de setembro de 1920 (LOO, 06/11/1920). Novamente, na falta de um acordo sobre o tema no seio do próprio conselho, optou-se pela abertura do debate.

Frente às acusações de Lauzet sobre as intenções divisionistas e sectárias, tanto de Zinoviev como daqueles que se inclinavam pela adesão à convocatória da IC argumento favorito do autor, ao lado de citações de Marx para corroborar a proeminência dos sindicatos frente aos partidos -,levantaram-se Vicente Todaro e Bartolomé Senra Pacheco. Em um longo artigo publicado em duas partes, o primeiro fez questão de ressaltar, antes de começar sua exposição, que "com o objetivo de evitar que se me tome por "tercerista" ${ }^{\text {,1 }}$ ou coisa parecida, declararei com toda franqueza que sou sindicalista revolucionário". Em seguida, o companheiro de CF de Lauzet louvava o "significado histórico transcendental" da Circular Zinoviev e enumerava os "fins concretos e definidos" que a IC perseguia, a saber: destituir a burocracia sindical que impedia o desenvolvimento ativo das organizações operárias, orientar o operariado pela senda eminentemente revolucionária e, por fim, procurar o apoio definitivo e resoluto dos trabalhadores à Revolução Russa.

\footnotetext{
${ }^{11}$ Por 'tercerista' se designavam os militantes simpatizantes da Internacional Comunista.

\section{GANPHLAC}


Para Todaro, era completamente equivocado equiparar o pedido feito por Zinoviev com qualquer proposta já feita por qualquer outro partido político, fosse argentino ou não. A circular apresentava o problema da revolução proletária e convocava para uma ação que extrapolasse as demonstrações de apoio moral à Revolução Russa, manifestações que, ainda segundo o sindicalista, "valem muito pouco nos momentos solenes e angustiantes da história". O ferroviário ainda acusava de maliciosos aqueles que insinuavam que a adesão à IC feria a autonomia sindical e que apenas acreditava nisso quem pensava que, mesmo em determinados momentos históricos, "não se permite que se rompam 'suas modalidades características' [ $d a$ autonomia sindical]... se é que ela as tem". Na conclusão de seu artigo, Todaro afirmava (LOO, 30/10/1920):

Se a Revolução Russa não fosse um feito real e tangível, outra seria minha opinião a respeito da $3^{\text {a }}$ Internacional (...) porém, existindo aquela, nós, como revolucionários, estamos moralmente obrigados a defende-la

Bartolomé Senra Pacheco (LOO, 16/10/1920 (1)), por sua vez, afirmava no início de seu artigo que lhe resultava incômodo ocupar as colunas do semanário depois da "ridícula permissão outorgada pela maioria do Conselho para que o assunto fosse discutido nestas colunas". Contudo, a importância do assunto o fazia abrir mão de suas reservas, assim como a necessidade de "combater sem piedade a quantos pretendam fazer trocadilhos para ocultar o repúdio que a revolução russa lhes merece". Pacheco aderia à análise de Zinoviev de que uma das principais razões para capitulação do movimento sindical europeu - "do qual importamos todos os ensinamentos e imitações" - foi a restrição de suas lutas por melhorias parciais, atitude semelhante a "aquela praticada entre nós de combater a carestia de vida com base em greves tendendo ao aumento de salários".

Para o subsecretário, a principal questão levantada por Zinoviev para todas as organizações operárias era se estas continuariam caminhando pela perigosa via do reformismo. Ainda segundo Pacheco:

A esta pergunta concreta qualquer um que se estime como revolucionário a contestaria com uma negação; convém, por outro

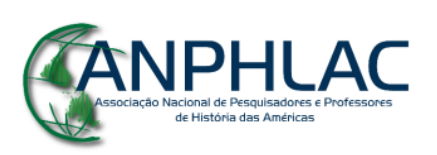


lado, reparar no escasso valor que teria essa negação teórica se os fatos ou a ação não marchassem na retaguarda dessas teorias.

O sindicalista procurava evidenciar o que seria uma contradição entre a retórica revolucionária da FORA IX ${ }^{\circ}$, presente "ao fim de todas as comunicações verbais e escritas" e sua Carta Orgânica. Para exemplificar a "enorme distância que separa as palavras dos atos", retomou as discussões sobre o desemprego realizadas durante a conferência da OIT, em Washington, em novembro de 1919, Pacheco mencionou a intervenção dos delegados operários Gino Baldesi da Itália e Leon Jouhaux da França ambos membros da Federação Sindical Internacional, da qual a FORA IX ${ }^{\mathbf{0}}$ era membro - quando estes tratavam de relacionar a desocupação operária com a escassez de matérias primas e sugeriram que a Liga das Nações organizasse a distribuição equitativa destas entre os países. Sobre o posicionamento dos delegados, Pacheco comentava:

Quer maior ingenuidade, para não falar um palavrão? A Liga distribuindo equitativamente o carvão que o capitalismo da Inglaterra e dos EUA tem especial interesse em açambarcar? (...) A Liga fazendo indiretamente o bem-estar da classe trabalhadora ao 'obrigar' aos ilustres capitalistas nela representados a abdicar do que obtiveram ao custo da guerra.

Em contraposição,

Não seria mais prático e mesmo mais revolucionário dirigir-se diretamente aos trabalhadores ingleses, aos mineiros, e incitá-los em nome dos interesses e necessidades de classe a que assumissem a administração das minas e o controle da distribuição de seus produtos?

A acusação de que a IC estaria promovendo a cisão no movimento operário era desqualificada por Senra Pacheco, pois, ao contrário, os bolcheviques buscavam unificar e identificar as organizações operárias em aspirações e propósitos. O chamado nada mais significava que as federações sindicais deveriam se unificar primordialmente pela revolução. A autonomia do movimento sindical em nada seria afetada já que as organizações haviam sido convidadas a ingressarem na IC como seções.

Foi ao final de seu texto que Pacheco abordou não só um dos cernes da polêmica instaurada na FORA IX ${ }^{\circ}$ pela "Circular Zinoviev", como também demonstrou uma guinada radical em seu posicionamento. Senra Pacheco, por fim, atacava o princípio de

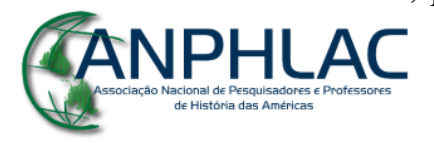


autonomia ideológica e da não vinculação da federação a grupos políticos. Em primeiro lugar, a adesão da federação à IC não poderia ser entendida como uma subordinação política, já que o Partido Comunista diferia totalmente daqueles partidos com propostas eleitorais e reformistas que a FORA IX ${ }^{\mathrm{o}}$ repudiava. O Partido Comunista propagava uma política de classe que não tinha nada a ver com o sufrágio universal. Por fim, sentenciava Pacheco (LOO, 23/10/1920):

Estimo que, sim, a revolução a que estamos convocados deverá operar-se fundamentalmente no terreno da produção e troca, o que lhe dá um caráter essencialmente econômico, porém seria negar as consequências do materialismo histórico esquecer que a superestrutura política tem estreita ligação e vinculação com a economia e deve ser e será transformada ao mesmo tempo.

Figura proeminente na organização, Bartolomé Senra Pacheco ganhou certo destaque ao substituir Sebastián Marotta durante o período em que o secretário da FORA IX ${ }^{\mathbf{o}}$ havia ido à Europa. As colocações de Pacheco, que havia sido um dos partidários da fundação da federação em 1915 (GODIO, 1988; BILSKY, 1995; SURIANO, 2009) e defendido a precedência da organização sobre os posicionamentos ideológicos em diversas ocasiões ${ }^{12}$, entravam em choque frontal com a principal bandeira da direção Sindicalista Revolucionária da FORA IX ${ }^{\circ}$. A ruptura proposta pelos bolcheviques e pela IC começava a ganhar adeptos no seio da direção Sindicalista Revolucionária.

O movimento grevista na Argentina, em um contexto de avanço em relação às pautas organizativas e de reversão dos resultados positivos, parecia haver chegado ao seu limite. Nesse contexto de reversão dos resultados das greves, incremento da atividade patronal e afastamento do governo, alguns setores do Sindicalismo Revolucionário começaram a abrir mão da neutralidade política por uma definição ideológica mais radical - setor que poderíamos denominar de esquerda, identificado aqui com os posicionamentos de Vicente Todaro e Bartolomé Senra Pacheco -, enquanto outros - a direita Sindicalista Revolucionária, identificada com os posicionamentos de Sebastián Marotta e Luiz Lauzet - apregoavam a necessidade de

\footnotetext{
${ }^{12}$ Ver seu posicionamento no IX ${ }^{\circ}$ Congresso de 1915 (SANTILLAN, 2005 (1933), p. 237); discurso na cerimônia do Primeiro de Maio de 1919 (LOO, 10/05/1919); posicionamento durante o Congresso Extraordinário da F.O.R.A. IX em junho de 1919 (LOO, 05/07/1919; LV, 01/07/1919).
}

\section{GANPHLAC}


fortalecimento do organismo de classe sob o império da neutralidade ideológica como única forma de sobrevivência.

\section{Uma decisão de cúpula?}

Em seu livro de memórias, o deputado Socialista Nicolás Repetto, ao comentar os efeitos da Revolução Russa na Argentina, destacava a "sinceridade" com que esses eventos foram recebidos pela classe trabalhadora argentina (REPETTO, 1956, p. 236):

Não foi o efeito de um sistema de propaganda posto a cargo de agentes do governo triunfante [bolchevique], senão a consequência de um movimento que fez estremecer o mundo de temor e esperança. Uma parte considerável de nossa classe operária acreditou ver nos feitos tão dramáticos que ocorriam na Rússia a solução do problema social há tanto tempo esperada.

O entusiasmo pela Revolução Russa extrapolou, em grande medida, as direções das organizações operárias e de esquerda, servindo, como afirma Andrea Doeswijk, de um verdadeiro catalisador no contexto social da crise econômica e da rebelião social da época na Argentina (DOESWIJK, p. 53). Independentemente das orientações ideológicas, as discussões sobre os eventos na Rússia produziram uma série de rearranjos naquelas organizações. $\mathrm{Na} F O R A \mathrm{IX}^{\mathrm{o}}$ não foi diferente.

As discussões sobre a Circular Zinoviev ocorreram poucos meses antes da realização do $\mathrm{XI}^{\circ}$ Congresso da FORA, em janeiro de 1921. Em artigos publicados no mês de outubro de 1920 (LOO, 16/10/1920 (2); 23/10/1920), a direita Sindicalista Revolucionária - novamente representada aqui por Luiz Lauzet e Sebastián Marotta passou a discutir a necessidade de que o próximo congresso se dedicasse à consolidação das modificações organizativas. Porém, a partir de novembro, os textos divulgados pela direita Sindicalista Revolucionária deixaram de lado o entusiasmo sobre o congresso e suas pretensas realizações e adotaram um tom alarmista e catastrofista sobre um espectro que rondava a organização: a adesão à IC. Para Marotta, discutir organização em vez de adesão à IC não era uma postura reformista, uma vez que "Falar de revolução sem deter-se em criar ou coordenar os órgãos da revolução será tudo o que se queira, mas não é revolucionário" (LOO, 13/11/1920).

\section{GANPHLAC}


Para desespero da direita Sindicalista Revolucionária, como resultado da consulta realizada pela direção com os seus diversos sindicatos sobre quais das pautas deveriam ser discutidas no congresso, quase nenhum enviou questões relativas à carta orgânica da entidade. Por outro lado, abundaram propostas sobre as pautas ditas "políticas", todas contrariando as orientações da direita sindicalista revolucionária. Nos informes sobre as respostas dos sindicatos aderidos ao Conselho Federal da organização, prevaleceram propostas de colaboração com os partidos de esquerda (socialistas, comunista ou ambos), adesão à IC e formação de uma frente única com a federação anarco-sindicalista.

Durante todo o mês que antecedeu o $\mathrm{X}^{\mathrm{o}}$ Congresso, em fevereiro de 1921, a direita sindicalista revolucionária se esforçou, fosse no La Organización Obrera ou em outras publicações operárias, para deslegitimar a proposta de adesão à IC (LOO, 01/01/1921; 01/01/1921 (2); 08/01/1921; 08/01/1921 (2); 15/01/1921; 22/01/1921). Nesse quesito, estes ganhariam o apoio tático dos militantes sindicais ligados ao Partido Socialista, que naquele momento também se viam em apuros com a pressão de suas bases pela adesão à Revolução Bolchevique (LV, 26/01/1921; 27/01/1921).

Durante a realização do $\mathrm{XI}^{\circ}$ Congresso da FORA na cidade de La Plata, entre os dias 29 de janeiro e 4 de fevereiro, as tentativas da sui generis aliança entre setores da direção Sindicalista Revolucionária e de seus arqui-inimigos socialistas para barrar a filiação da federação à IC, foram prontamente rechaçadas pelo plenário ${ }^{13}$. Recontagem de votos, inundação de moções, inversões de pauta e todo o tipo de táticas para implodir qualquer votação nesse sentido foram utilizadas pelas mais diversas forças políticas ali representadas. O resultado foi uma verdadeira batalha entre a direção da organização, a plateia e os delegados sindicais; representantes e representados enfrentavam-se uns alheios aos outros e não mais se compreendiam. Restou aos representantes abrirem mão dos representados, proibindo a entrada da plateia nas últimas sessões do congresso. Apesar do sucesso de Socialistas e Sindicalistas Revolucionários em postergar a votação sobre a adesão da federação à IC, o esforço custou a perda da direção da federação por parte da direita Sindicalista Revolucionária. A eleição para o novo Conselho Federal instalou na direção da principal organização sindical do país uma maioria simpática ou

\footnotetext{
${ }^{13}$ Para uma crônica desse congresso, ver: LV 30/01/1921 à 07/02/1921; LOO, 29/01/1921; 12/02/1921; Boletin de Servicios de la Asociación del Trabajo (BSAT), 1921.
}

\section{CANPHLAC}


declaradamente favorável à adesão à IC. Luis Lauzet, Sebastián Marotta, Luis Bartolo e Juana Pallas, antigos membros do Conselho Federal e figuras de proa do grupo identificado com a direita Sindicalista Revolucionária não chegaram a conseguir os votos necessários sequer para serem eleitos como suplentes do conselho.

\section{Considerações finais}

Não obstante a clara opção pela radicalização, os membros do novo Conselho Federal da FORA IX ${ }^{\circ}$ tiveram pouco tempo para imprimir uma nova direção política ao movimento organizado dos trabalhadores argentinos. Às vésperas de declarar uma greve geral contra os ataques das organizações patronais contra os marítimos e portuários, ao fim de maio e início de junho de $1921^{14}$, a maior parte de seus delegados foi encarcerada e as sedes de seus sindicatos invadidos. $\mathrm{O}$ desmantelamento da federação por forças policiais e paramilitares, mas principalmente de seu mais importante sindicato, a Federación Obrera Marítima, foram um marco do início do que Charles Maier chamou de terceiro e último período da onda revolucionária mundial, marcada pelo refluxo das mobilizações e pela fragmentação política das esquerdas. Bartolomé Senra Pacheco, recém eleito secretário-geral da FORA IX ${ }^{o}$ e um dos entusiastas da adesão da organização à IC, contraiu uma pneumonia durante sua prisão, naquelas semanas de fins de maio e início de junho, que o levou à morte no dia 8 de julho de 1921, aos 31 anos. Encerrava-se assim a onda de greves em Buenos Aires e a hegemonia política dos Sindicalistas Revolucionários. A direção do movimento operário argentino somente seria hegemonizada por alguma força política de tal maneira mais de vinte anos depois, durante o contexto de ascensão do movimento peronista.

As discussões provocadas pela Revolução Russa, sobretudo após a divulgação da Circular Zinoviev, tiveram como pano de fundo a dramática situação pela qual o movimento operário argentino passava naquele momento. A mobilização dos trabalhadores argentinos, em um contexto de reversão dos resultados positivos e de avanço em relação às pautas organizativas - ou seja, políticas -, somado ao crescente

\footnotetext{
${ }^{14}$ Para a reconstituição dos conflitos iniciados no porto de Buenos Aires e que desembocaram na greve de junho de 1921, além da documentação c, utilizamo-nos dos seguintes trabalhos: ADELMAN, 1993, p. 73102; CARUSO, 2012, p. 365-379; DOESWIJK, 1998., p. 134-137, 157-161 e 170-172; DEUTSCH, 2003, p. 119-118; HOROWITZ, 1995, p.. 57-79; RAPALO, 1997, p. 216-225.
}

\section{GANPHLAC}


entusiasmo das bases e de atividade e violência patronal, chegava ao seu limite. Esse impasse, coroado pelo abandono do decisivo, porém relativo, apoio ao movimento operário pelo governo Yrigoyen também levou em grande medida ao limite a capacidade de direção do movimento por parte dos Sindicalistas Revolucionários: a defesa das organizações de classe acima de qualquer outro objetivo ou a ampliação do enfrentamento?

Assim como nos agrupamentos políticos já estuados pela historiografia, os debates em torno do processo revolucionário russo que tomaram de assalto a principal organização sindical do país, muito mais que um mero reflexo, ou simulacro sem nenhum tipo de mediação, foram os meios pelos quais os trabalhadores e sindicalistas expressaram dilemas bem concretos que enfrentavam naquele momento.

\section{Bibliografia:}

ADELMAN, Jeremy, "State and Labour in Argentina: The Portworkers of Buenos Aires, 1910-21", Journal of Latin American Studies, Vol. 25, No. 1 (Feb., 1993), pp. 73-102.

ARÉVALO, Oscar, El Partido Comunista, Buenos Aires: CEAL, 1983.

BILSKY, "Esbozo de la historia del movimiento obrero argentino: desde sus orígenes hasta el advenimiento del peronismo", in Cuadernos Símon Rodriguez, No 3, Buenos Aires: Fundación Símon Rodriguez-Editorial Biblos, 1995.

BREWESTER SMITH, L. e COLLINGS, Harry T., "The Economic position of Argentina during the war", in Economic studies of countries during the war, $\mathrm{N}^{\circ} 88$, Washington: Government Printing Office, 1920.

BUNGE, Alejandro, FERRARI, Ludovico A. e VALLE, Juan Carlos, "Costo de la vida en la Argentina de 1910 a 1919", Revista de Economía Argentina, TOMO IV, Fevereiro de 1920, p. 253-260.

CAMARERO, Hernán, A la conquista de la clase obrera: los comunistas y el mundo del trabajo en la Argentina, 1920-1935, Buenos Aires: Siglo XXI, 2007.

CARONE, Edgar, “A Internacional Comunista e as 21 condições”, 2003 in Gramsci e o Brasil, disponível em http://www.acessa.com/gramsci/?page=visualizar\&id=109.

CARUSO, Laura G., Los trabajadores marítimos del Puerto de Buenos Aires: condiciones laborales, organización sindical y cultura politica,1890-1920, Tese (Doutorado em História) - Facultad de Filosofia y Letras Universidad de Buenos Aires, Buenos Aires, 2012.

\section{GANPHLAC}


CORBIÉRE, Emilio J., Orígenes del comunismo argentino (La fundación del Partido Socialista Internacional), CEAL: Buenos Aires, 1984.

CORTES CONDE, Roberto, "Tendencia de laevolucion de los salários reales en Argentina, 1880-1910. Resultados preliminares", Económica, № 2-3, Maio dezembro de 1976.

CÚNEO, Dardo, Comportamiento y crisis de la clase empresaria, Buenos Aires: CEAL, 1984.

DEL MAZO, Gabriel, La primera presidencia de Yrigoyen, Buenos Aires: CEAL, 1986.

DEUTSCH, Sandra McGee, Contrarevolución en Argentina, 1900-1932: La Liga Patriótica Argentina, Bernal: Universidad Nacional de Quilmes, 2003.

DI TELLA, Guido e ZYMELMAN, Manuel, Los ciclos económicos argentinos, Buenos Aires: Editorial Paidós, 1973.

DOESWIJK, Andreas L., Entre camaleões e cristalizados: os anarco-bolcheviques Rioplatenses, Tese (Doutorado em História) - Instituto de Filosofia e Ciência Humanas, Universidade Estadual de Campinas, Campinas, 1998.

FALCÓN, Ricardo e MONSERRAT, Alejandra, "Estado, empresas, trabajadores y sindicatos" in Nueva Historia Argentina: Democracia, conflicto social y renovación de ideas (1916-1930), Tomo VI, Org. FALCÓN, Ricardo. Buenos Aires: Editorial Sudamericana, 2000.

FALCÓN, Ricardo, "Políticas laborales y relación Estado-sindicatos en el gobierno de Hipólito Yrigoyen (1916-1922)”, in La cuestión social en Argentina: 1870-1943, Buenos Aires: Editorial La Colmena, 2000.

FLORA, Peter, KRAUS, Franz e PFENNING, Winfried. State, Economy, and Society in Western Europe, 1815-1975. Volume II: The Growth of Industrial Societies and Capitalist Economies, Frankfurt, Campus Verlag; Londres, Mcmillan Press; Chicago, St. James Press, 1987.

FRANZOSI, Roberto, The puzzle of strikes: class and state strategies in post war Italy, Cambridge: Cambridge University Press, 1995.

GODIO, Julio. El movimineto obrero argentino (1910-1930): socialismo, sindicalismo y comunismo. Buenos Aires: Editorial Legasa, 1988.

GOLDEBERG, Heidi, Railroad Unionization in Argentina, 1912-1929: The limitations of working classes alliance, Ph.D., Yale University, 1979.

GUTIÉRREZ, Leandro H. e ROMERO, Luis Alberto, Sectores populares, cultura y política: Buenos Aires en la entreguerra, Buenos Aires: Sudamericana, 1995.

HOBSBAWM, Eric, A Era dos Extremos: o breve século XX: 1914-1989. São Paulo: Companhia das Letras, 1995.

HOROWITZ, Joel, “Argentina's Failed General Strike of 1921: A Critical Moment in the Radicals' Relations with Unions", The Hispanic American Historical Review, Vol. 75, No. 1 (Feb,1995), pp. 57-79.

\section{GANPHLAC}

Revista Eletrônica da ANPHLAC, ISSN 1679-1061, №. 25, p. 28-55, Jul./Dez., 2018.

http://revista.anphlac.org.br 
HOROWITZ, Joel, "Los trabajadores ferroviarios en la Argentina (1920-1943). La Formación de una elite obrera", Desarrollo Ecónomico, Vl. 25, № 99, 1985.

HORWITZ, Joel, "El movimiento obrero", in Nueva Historia Argentina:Crisis económica, avance del Estado e incertidumbre política, Tomo VII, Org. CATTARUZZA, Alejandro, Buenos Aires: Editorial Sudamericana, 2001.

IÑIGO CARRERA, Héctor J., La experiencia radical, Buenos Aires: Ediciones La Bastilla, 1980.

IÑIGO CARRERA, Juan, La Formación Económica de la Sociedad Argentina: Renta agraria, ganancia industrial y deuda externa. 1882-2004, Vol. I, Buenos Aires: Imago Mundi, 2007.

ISCARO, Rubens, Historia del movimiento sindical, Buenos Aires: Fundamentos, 1973.

LUNA, Félix, Yrigoyen, Buenos Aires: Hyspamerica, 1985 (1954).

MAIER, Charles. Recasting bourgeois in Europe: stabilization in France, Germany and Italy in the decade after World War I. Princeton: Princeton Universty Press, 1988.

MARCHESE, Silvia M., "Estrategias de las organizaciones empresariales para su participación política", in Nueva Historia Argentina: democracia, conflicto social y renovación de ideas (1916-1930), Tomo VI, org. Ricardo Falcón , Buenos Aires: Editorial Sudamericana, 2000.

MAROTTA, Sebastian. El movimiento sindical argentino,su genisis y desarrollo, Tomo III (1920-1935). Buenos Aires: Editorial Calmino, 1970.

MATSUSHITA, Hiroshi. Movimiento obrero argentio, 1930-1945: sus proyecciones en los orígenes del peronismo. Buenos Aires: Ediciones Siglo Veinte, 1983.

MAYER, Arno. The Furies: Violence and Terror in the French and Russian Revolutions, New Jersey: Princeton University Press, 2000.

ORIOLO, Jordán, Antiesbozo de la historia del Partido Comunista, Buenos Aires: CEAL, 1994.

PALACIO, Juan Manuel, "La antesala del peor: la economía argentina entre 19141930" in Nueva Historia Argentina: democracia, conflicto social y renovación de ideas (1916-1930), Tomo VI, org. Ricardo Falcón, Buenos Aires: Editorial Sudamericana, 2000.

PASSALACQUA, Eduardo H., "Noticia Preliminar sobre el Pensamiento Yrigoyenista", in Yrigoyen: Su pensamento escrito, Dir. Comité Nacional de la Unión Cívica Radical, Buenos Aires: Pequén Ediciones, 1984.

PEÑA, Milciades, Masas, caudillos y elites: La dependencia argentina de Yrigoyen a Perón, Buenos Aires: Editores Fichas, 1971.

PETERSON, Florence. Strikes in the United States, 1880-1936, Washington, U.S. Governement print office, 1938.

\section{GANPHLAC}


PITTALUGA, Roberto, "De profetas a demonios: Recepciones anarquistas de la Revolución Rusa (Argentina 1917-1924)". Sociohistórica, (11-12), 2002, p.69-98. Disponível em: http://www.memoria.fahce.unlp.edu.ar/art_revistas/pr.3061/pr.3061.pdf

PUIGGRÓS, Rodolfo, Yrygoyenismo, Buenos Aires: Corregidor, 1974.

RAPALO, María Ester, Patrones y obreros: La ofensiva de la clase proprietaria, 19181930, Buenos Aires: Siglo Vientiuno Editores, 2012.

RAPALO, María Ester, Patrones y obreros: La ofensiva de la clase proprietaria, 1918 1930, Buenos Aires: Siglo Vientiuno Editores, 2012, pp. 117-138.

REPETTO, Nicolás, Mi paso por la política - De Roca a Yrigoyen, Buenos Aires: Santiago Rueda Editor, 1956.

ROCK, David, El Radicalismo argentino, 1890-1930, Buenos Aires: Amorrortu Editores, 2010 (1977).

ROCK, David, El Radicalismo Argentino, 1890-1930, Buenos Aires: Amorrortu Editores, 1997, pp. 216-225.

SANTILLAN, Diego Abad, La F.O.R.A.: ideologia y trayectoria, Buenos Aires: Libros de Anarres, 2005 (1933).

SCHVARZER, Empresarios del pasado: la Unión Industrial Argentina, Buenos Aires: Imago Mundi, 1991.

SURIANO, Juan, Auge y caída del anarquismo, Buenos Aires: Capital Intelectual, 2009.

TILLY, Charles, "The effects of short-term variation - Introduction", in Strike, wars and revolution in an international perspective: Strikewaves in the late nineteenth and early twentieth centuries, Dir. Leopold H. Haimson e Charles Tilly Cambrigde: Cambrigde University Press, 1989.

V.A., "Sítntesis Estadísticas de la República Argentina, e deflacionado pelo IPC" FERRERES, Orlando J. (Dir.), Dos siglos de economía argentina, Buenos Aires: El Ateneo, 2010.

\section{Documentos:}

\section{La Organización Obrera (LOO)}

“La conmemoración del Primero de Mayo", LOO, 10/05/1919

“El Congreso Extraordinario de la F.O.R.A.”, LOO, 05/07/1919

"Ante el crecimiento de la F.O.R.A.: Necesidad de reogranizar su mecanismo", LOO, 23/04/1920.

"Reuniones del Consejo Federal", LOO, 18/09/1920.

\section{GANPHLAC}


“Más sobre la circular Zinovieff”, LOO, 25/09/1920.

"Mantengamos la unidad sindical", LOO, 02/10/1920.

“La circular de Zinovieff”, LOO, 16/10/1920 (1).

"Undécimo Congreso de la F.O.R.A - Será una transcendental asamblea del Trabajo"(2), LOO, 16/10/1920

"Perspectivas del próximo congreso federal - Consideraciones previas", LOO, 23/10/1920.

"La circular de Zinovieff (continuación)", LOO, 23/10/1920.

"La circular Zinovieff - su verdadero significado histórico - continuación", LOO, $30 / 10 / 1920$

"Reuniones del Consejo Federal”, LOO, 06/11/1920

“Perspectivas del Congreso - El lugar de su realización”, LOO, 13/11/1920.

“Juicios de la prensa sindical”, LOO, 01/01/1921 (1).

"Proposiciones encontradas - La F.O.R.A. y la prescidencia", LOO, 01/01/1921 (2).

“Se plantea la creación de grupos comunistas", LOO, 08/01/1921 (1).

"Por encima de todo: la unidad obrera nacional e internacionalmente", LOO, 08/01/1921 (2).

"Juicios de la prensa sindical", LOO, 15/01/1921

"Juicios de la prensa sindical", LOO, 22/01/1921

“Al inaugurarse el XI Congreso", LOO, 29/01/1921.

“Crónica: Undécimo Congreso", LOO, 12/02/1921

\section{LA VANGUARDIA (LV)}

"El Congreso Gremial: Cronica de la cuarta y quinta sesiones", $L V, 01 / 07 / 1919$

"El Congreso de la FORA y los delegados socialistas", $L V, 26 / 01 / 1921$;

"La fuerza del movimiento proletario", $L V, 27 / 01 / 1921$

“Crónica del Congreso de la FORA”, LV, 30/01/1921 à 07/02/1921.

\section{FSI}

"Fluctuations des Effectifs des Centrales Nationales affilieés à la F.S.I.", VIII Annuaire de la Federation Syndicale Internationale. Paris, 1938.

\section{GANPHLAC}




\section{BSAT}

"Cronica del movimiento obrero - El XI Congreso de la FORA", Boletin de Servicios de la Asociación del Trabajo, Ano II, No 26, 1921.

\section{DSCD}

Diario de Sesiones de la Cámara de Diputados, TOMO I, Maio-Junho de 1919, p. 165172.

\section{DNT}

Boletín del Departamento Nacional del Trabajo, Buenos Aires: D.N.T., No 33, Vol. X, Janeiro de 1916, pp. 5-316

NIKLISON, José Elías, “Las organizaciones Obreras de Buenos Aires”, in Boletín del Departamento Nacional del Trabajo, No41, 1919

Crónica Mensual del Departamento del Trabajo (№19, Vol. II, Julho de 1919, pp. 290294; No 20, Vol. II, Agosto de 1919, pp. 305-310; No 29, Vol. III, Maio de 1920, pp. 457-462; No 53, Vol. V, Maio de 1922, pp. 861-866; Nº 88, Vol. VIII, Abril de 1925, pp. 1564-1566; No 127, Vol. XI, Setembro de 1928, pp. 2505-2510),

Estadísticas de las huelgas, Buenos Aires: DNT, 1940.

\section{GANPHLAC}

